$$
\begin{aligned}
& \text { 脾サルコイドーシスの } 1 \text { 例 } \\
& \text { 東京女子医科大学第 } 2 \text { 外科, 同 呼吸器外科* } \\
& \text { 廣 澤 知一郎 瀨下明良亀岡信悟 } \\
& \text { 村 柇 雅 秀* 大 貫 恭 正* }
\end{aligned}
$$

今回われわれは比較的稀な脾サルコイドーシスの 1 例を経験した.症例は71歳女性で, 肺サルコイドーシスの手術後, 腹部 CT にて脾臟に結節像を認め, 経過観察するも次第 に増大, 多発傾向を示したため, 摘脾術を施行した。本邦で報告された脾サルコイドー シスは12例あり，そのうち5例が脾原発悪性腫場を否定でぎ，摘脾術を施行し術後病 理で診断されていた，手術を施行しなかった他の7例洁肝病変も認め, 肝生検により診

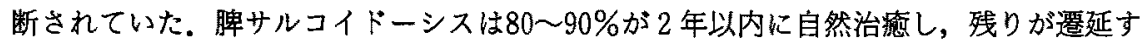
るといわれている゙かが, 問題点としては増大, 増加傾向を示す症例に対しての治療法であ ると思われる. 治療法にはステロイド療法と手術があるが, 本症例では脾腫瘍が増大し た時点で全身状態が落ち着いており, 他病変がないことと, 脾原発腫瘍も否定できない ことから手術に踏み切った.この様な症例では確定診断するという点からも手術の適応 であると思われた。

索引用語：サルコイドーシス, 脾㵴

\section{緒 言}

サルコイドーシス症の肺外病変としての脾病変は, 他覚所見に比較的乏しいことなどの理由から発見され ず，その報告例は少ない.今回われわれは肺サルコイ ドーシスにて手術を施行し, 経過観察中, 腹部 CTに て脾臓に多発する結節像を認め摘脾術を施行し, 術後 病理所見で脾サルコイドーシスと診断した稀な症例を 経験したので，本邦で報告されている脾サルコイドー シス12例の検討を含め報告する。

\section{症 例}

患者：71歳，女性.

主訴：なし。

既往歴：平成 12 年 9 月肺サルコイドーシスにて右上 葉切除。

家族歴：特記すべきことなし.

現病歴：平成12年 9 月右上葉に腫瘍を認め (図 1 ), 肺癌の馀断で当院呼吸器外科にて右上葉切除術を施行 した. 術後病理は肺サルコイドーシスであった。肺単

2002 年 7 月 9 日受付 2002 年11月12日採用

〈所属施設住所〉

T162-8666 東京都新宿区河田町 8 - I
独病変であったためステロイドは使用せず外来で経過 観察していた。平成13年 2 月 CTにて脾腫湯を認め経 過観察したが，増大傾向を認めたため，手術目的に平 成14年 3 月 8 日当科入院となった。

入院時現症：結膜，眼底とも正常. 皮膚正常. 血圧 $123 / 70 \mathrm{mmHg}$, 脈拍78/分. 胸腹部に異常なく, 表在り ンパ節は触知しなかった。また神経学的にも異常所見 を認めなかった。

入院時検查所見：血液，生化学所見に異常所見注認 めず, ACEは21.6IU/1で正常であった。また腫湟マー カーは CEA 2.2ng/ml, CA19-9 13U/ml で正常であっ た。

腹部超音波検查：脾臟に $2 \mathrm{~cm}$ 大の境界明膫な低工 コーの結節を 1 個認めた.

腹部 CT (平成13年 2 月，平成14年1月)（図 2 ）：平 成 13 年 2 月の造影 CT (上) では $2 \mathrm{~cm}$ 大の低濃度結節 を 1 個認めた。平成14年 1 月の単純 CT (中) では結節 影は明らかでなかったが, 造影 CT (下) では境界明睹 な多数の低濃度結節を諗め,大きさは $3 \mathrm{~cm}$ 大に增大 した。

腹部 MRI（平成14年 1 月）(図 3 )：T 1 強調画像 （左）では明らかな異常は認めなかったが，T2強調 


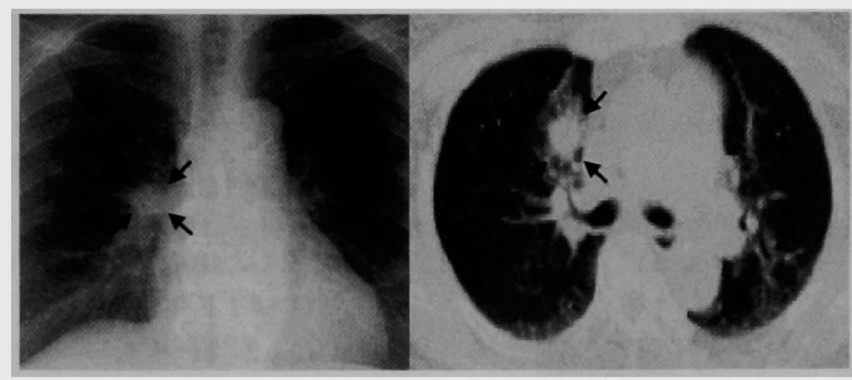

図 1 胸部 X 線写真およひ胸部 CT：右上肺野に直径 $2 \mathrm{~cm}$ 大の腫瘍 性病変を認める。

（右）で境界明瞭な低信号の結節を多数認め，腫煌径 も增大していた。

臨床経過から脾サルコイドーシスを疑ったが、約 1 年の間で腫鹰が増大し，多発傾向を示し，また他臟器 にサルコイドーシス病変を認めなかったことや ACE も正常であったことから脾原発悪性腫瘍も否定でき ず，腹䏸鏡補助下脾臓摘出術を施行した。術中所見は 肝を含め多藏器に異常を認めなかったが，脾周囲に炎 症性と思われる疮着を認め, 豩離操作に難渋した。

摘出標本 (割面) の肉眼所見 (図4)：脾蔵に黄白色 から黄褐色の弾性硬の腫瘤が散在し，その最大径は 3 cmであった。

組織学的所見（図 5 ）：左）（×2）脾缄内部に孤立 性ないし空合性の大小の結節が存在した（ム印）。右）

$(\times 10) こ れ ら の$ 結節はさらに小さな結節で構成され ており，好酸性の豊かな包体から成る類上皮性組織球 の集団を認め( $\Delta$ 印)，多核巨細胞が混在する(“印). またその中央部には非乾酪性の壤死層が見られている (*印).以上の所見から脾サルコイドーシスと診断し た.

\section{現在外来通院中であるが経過良好である。 考 察}

サルコイドーシスは壊死を伴わない類上皮細胞肉芽 腫により形成される病変を主徵とし，主に綐隔，肺， 皮㨐, 網膜を侵す原因不明の全身性疾患であり, 通常 その典型的な臨床症状や胸部単純写真により大部分の 症例が診断されている゙．腹腔内病変も稀にみられる が潜在性のものがほとんどで，その場合肺門リンパ節 腫大のようなサルコイドーシスに特徽的な症状を伴っ ていることが多い21.また，脾に多発性結節影を呈する 場合, 超音波, CT, MRI 所見にて, 脾原発悪性腫場と の籃別することは難しく，血管造影や腹腔鏡が試みら
れているが困難とされている゙1!．いずれの場合も確定 診断け，病理組織学的所見によりなされている．本症 例は肺サルコイドーシスで肺部分切除し, 外来で経過 観察中, 脾腫場を指摘された。臨床経過より脾サルコ イドーシスが疑われたため経過観察していたが腫場の 増大傾向を認め, 脾原発悪性腫場を否定できないため 摘脾術を施行し、病理組織学的所見により脾サルコイ ドーシスと診断した。

本邦で脾サルコイドーシスの報告例は表 1 に示すよ うに1990年から 2002 年までの13年間で自験例を含めて 13例であった，年路は症例 $6,8 ， 9$ を除きいずれも 50 歳代で症例 6 ，て以外は全例女性であった。主訴は 記載のあった 4 例では倦意感が 2 例と最も多く, 症例 5 のように乳癌術前検查で見つかった症例もあった。 超音波所見では記載のあった 6 例すべて低エコーの多 発結節として描出されていた。（丁所見は単純 CTで は腫瘤陰影は認めないが, 造影 CT で多数の低濃度結 節がみられるという症例がほとんどであった．発見時

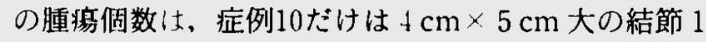
個で単発性であったが他はすべて多発結節であった。 自験例は発見時単発病変であったか，約 1 年で腫瘍は 増大，多発した。このことはサルコイドーシスは肺が 先行する症例が多く, 肺の経過観察が中心となること や, 腹腔内病変は無症状で潜在する症例が多く, 偶発 的に発見されることが多いと思われた。.IIRI 所見は T 1 強調でははっきりとした異常所見はみられないが $\mathrm{T} 2$ 強調で低信号の多発結節を認めるのが特徵であっ た．いずれの検查所見も自験例と同様の所見であり， 脾サルコイドーシスに特巽的とはいえないが，一つの 特徴であると考えられた。手術した 6 例ひ術前診断で 脾サルコイドーシスと診断した症例はなく，いずれも 脾悪性腫瘄を否定しきれず手術を施行し，術後病理所 


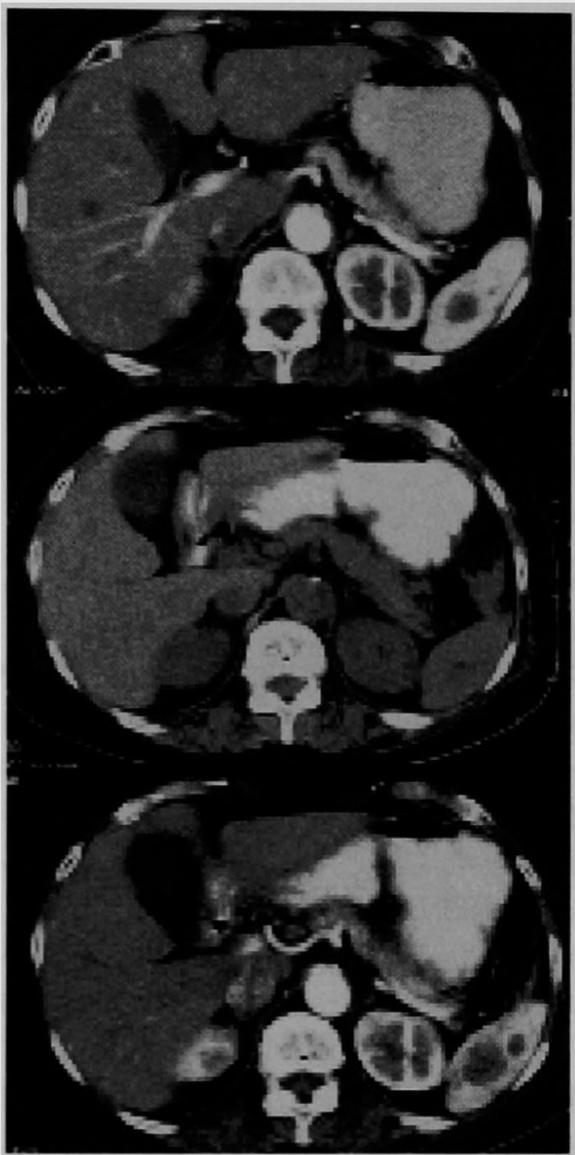

図 2 腹部造影 CT，単純 CT および造影 CT： 平成13年 2 月の造影 CT (上)で $2 \mathrm{~cm}$ 大の 低浱度結節を 1 個認めた。平成 14 年 1 月の単 純 CT (中) では結節影は明らかでなかった が, 造影 (T (下) では境界明瞙な多数の低瀑 度結節を認め, 大ききは $3 \mathrm{~cm}$ 大に增大した。 $\frac{\text { 平成13年 } 2 \text { 月 }}{\text { 平成14年 } 1 \text { 月 }}$
見で確定診断している，手術を施行しなかった 6 例は 併存する肝病変からの生検でサルコイドーシスと診断 し, そのうち 4 例の治療法の記載はなかったが, 症例 8, 9 はステロイド療法で腫瘍の縮小効果を得ていた。 脾サルコイドーシスに合併する腹腔内病変としては肝 が最も多く，40\%近くの症例に肝病変を認めていた。

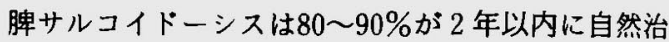
瘜し, 残りが遷延するといわれている21. 症状がなけれ ば経過観察するが，症状がある場合あるいは增大，增 加傾向を示す症例に対しての治療法が問題となる。 ど こまで経過観察するかの基準はなく，症例毎に治療か 検討されているのが現状であろう。治療法にはステロ イド療法と手術があり，ステロイドは一般に縮小効果 はあるが長期予後には影響しないとの報告が多く，心 病変などを合併し生命の危機がある場合に行われる。 しかしながら脾病変が主体の症例はその適応はまだ不 明である. 全身状態が安定しており，他病変の合併が ない場合は手術が推奨されているが, 脾悪性腫瑒を否 定できないということが背景にあると思われる，本症 例では脾腫瘍が増大した時点で全身状態が安定してお

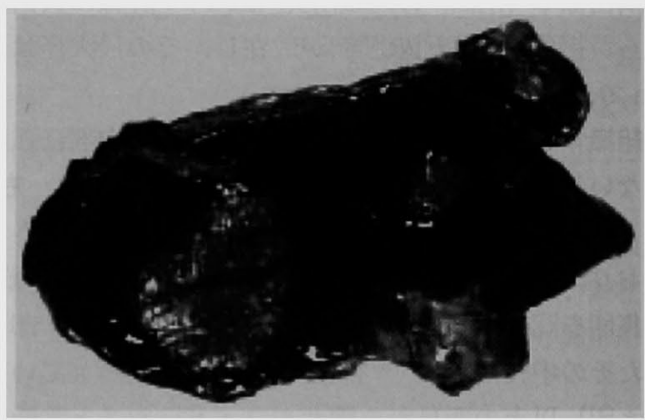

図 4 標出標本割面：脾臓に最大 $3 \mathrm{~cm}$ の黄白色から 黄褐色の腫㾕が散在していた。

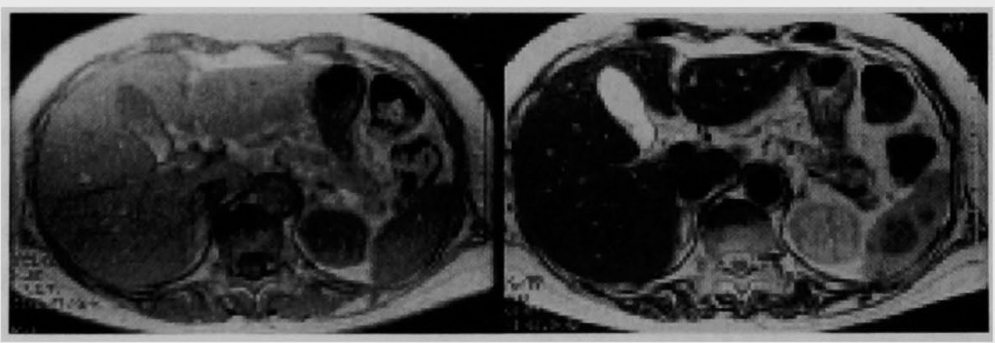

图 3 平成14年 1 月 MRI (左：T 1 強調, 右：T 2 強調)：T 1 強調 (左)では明ら かな異常は認めなかったか，T 2 強調（右）て境界明瞭な低倌号の結節を多数認 ぬた. 


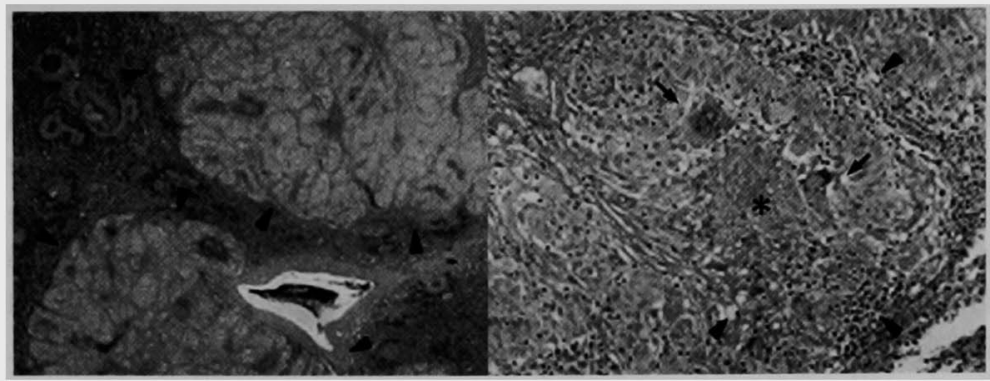

図 5 病理組織学的所見：左) $(\times 2)$ で脾䑏内部に孤立性ないし痹合性の大小の 結節が存在した ( $\Delta$ 印). 右)（×10）ではこれらの結節はさらに小さな結節で楎 成されており，好酸性の豊かな包体からなる類上皮性組織球の集団を認め（山 印), 多核巨練胞が混在する(†印)，またその中央部には非乾酪性の墳死首がみ られている (*印)。

表 1 脾サルコイドーシスの報告例(1990年〜2002年)

\begin{tabular}{|c|c|c|c|c|c|c|c|c|}
\hline 症例 & 報告者 & 主訴 & 超音波 & CT (enhance) & MRI & 術前㟝断 & 治撞 & $\begin{array}{l}\text { 脾炡以外 } \\
\text { の腹肤内 } \\
\text { 病変 }\end{array}$ \\
\hline $\begin{array}{c}<1> \\
59 \text { 叔女 }\end{array}$ & $\begin{array}{r}3) \\
\text { \#上5 }\end{array}$ & 倦志感 & $\begin{array}{l}\text { 低エコーの } \\
\text { 多発結節 }\end{array}$ & $\begin{array}{l}\text { 境界明明な多数の低 } \\
\text { 泿度結節 }\end{array}$ & $\begin{array}{l}\text { T2強調て境界明睰な } \\
\text { 低信号の結節 }\end{array}$ & 悪性リンパ & 手術 & なし \\
\hline $\begin{array}{l}<2> \\
51 \text { 歳女 }\end{array}$ & $\begin{array}{r}\text { 4) } \\
\text { 福地ら }\end{array}$ & なし & & 脾腫とリンパ節腫脹 & & 悪性リンパ & 手術 & なし \\
\hline$\langle 3\rangle$ & $\begin{array}{r}5) \\
\text { 諸見里 } \\
\end{array}$ & & & 広筑な索状影 & 広範な索状影 & $\begin{array}{l}\text { 肝生検で訮脾サ } \\
\text { ルコイドーシス }\end{array}$ & & 肝 \\
\hline $\begin{array}{l}<4> \\
53 \text { 崴女 }\end{array}$ & $\begin{array}{r}\text { 6) } \\
\text { 印牧5 } \\
\end{array}$ & $\begin{array}{l}\text { サルコイドー } \\
\text { シスで通院中 }\end{array}$ & $\begin{array}{l}\text { 肝舮腫と } \\
\text { 多発結節 }\end{array}$ & \begin{tabular}{|l|} 
肝脾腫と肝内に多数 \\
の低潡度結節
\end{tabular} & $\begin{array}{l}\mathrm{T} 2 \text { 強調て肝朝内に多 } \\
\text { 数の低信号の結節 }\end{array}$ & $\begin{array}{l}\text { 肝生検て肝脾サ } \\
\text { ルコイドーシス }\end{array}$ & & 肝 \\
\hline $\begin{array}{l}<5> \\
58 \text { 藏女 }\end{array}$ & $\begin{array}{r}\text { 7) } \\
\text { 滰端ら }\end{array}$ & $\begin{array}{l}\text { 秏思術前 } \\
\text { Stage I }\end{array}$ & & \begin{tabular}{|l|} 
境界明瞳な多数の低 \\
漕度結節
\end{tabular} & $\begin{array}{l}\text { T2強調で多数の低信 } \\
\text { 号の結節 }\end{array}$ & $\begin{array}{c}\text { 乳䁬轱移も否 } \\
\text { 定できす }\end{array}$ & $\begin{array}{c}\text { 二期的 } \\
\text { 手術 }\end{array}$ & なし \\
\hline $\begin{array}{l}<6> \\
27 \text { 劌男 }\end{array}$ & $\begin{array}{r}\text { 8) } \\
\text { 阿部ら }\end{array}$ & なし & $\begin{array}{l}\text { 肝脾嗹と } \\
\text { 多発結節 }\end{array}$ & $\begin{array}{l}\text { 肝と脾に多数の低濃 } \\
\text { 度結節 }\end{array}$ & $\begin{array}{l}\text { T2強調で多数の低信 } \\
\text { 号の結節 }\end{array}$ & $\begin{array}{l}\text { 肝生検で肝腌サ } \\
\text { ルコイドーシス }\end{array}$ & $\ldots$ & 肝 \\
\hline $\begin{array}{l}<7> \\
55 \text { 濊男 }\end{array}$ & $\begin{array}{r}\text { 8) } \\
\text { 阿部ら }\end{array}$ & なし & $\begin{array}{l}\text { 肝抙樋と } \\
\text { 多発結節 }\end{array}$ & 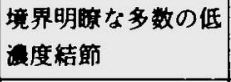 & $\begin{array}{l}\text { T2強調て境界明眱な } \\
\text { 低僧号の多㖑結節 }\end{array}$ & $\begin{array}{l}\text { 肝生検で肝脾サ } \\
\text { ルコイドーシス }\end{array}$ & & 坵 \\
\hline $\begin{array}{l}<8> \\
30 \text { 䠞女 }\end{array}$ & $\begin{array}{r}\text { 9) } \\
\text { 小林ら }\end{array}$ & & & $\begin{array}{l}\text { 肝と脾に多数の低浱 } \\
\text { 度結節 }\end{array}$ & & $\begin{array}{l}\text { 肝生検で肝脾サ } \\
\text { ルコイドーシス }\end{array}$ & $\begin{array}{r}\text { ステロ } \\
\text { イド }\end{array}$ & 坵 \\
\hline $\begin{array}{l}<9> \\
44 \text { 藏女 }\end{array}$ & $\begin{array}{r}\text { 9) } \\
\text { 小林ら }\end{array}$ & & & \begin{tabular}{|l|} 
訮と胿に多数の低漶 \\
度結節
\end{tabular} & & $\begin{array}{l}\text { 肝生蚞て肝脾サ } \\
\text { ルコイドーシス }\end{array}$ & $\begin{array}{r}\text { ステロ } \\
\text { イド }\end{array}$ & 肝 \\
\hline $\begin{array}{l}<10> \\
51 \text { 胔女 }\end{array}$ & $\begin{array}{r}10) \\
\text { 長浜ら }\end{array}$ & 右悽肋部痛 & & $\begin{array}{l}4 \mathrm{~cm} \times 5 \mathrm{~cm} \text { 大の低流 } \\
\text { 度結節 } 1 \text { 個 }\end{array}$ & $\begin{array}{l}\text { T2強謂で境界明瞭な } \\
\text { 低信号の結節 } 1 \text { 個 }\end{array}$ & 悪性嗹孺 & 手術 & なし \\
\hline $\begin{array}{l}<11> \\
59 \text { 咸女 }\end{array}$ & $\begin{array}{r}10) \\
\text { 長浜ら }\end{array}$ & 胸やけ & $\begin{array}{l}\text { 低エコーの } \\
\text { 多発結節 }\end{array}$ & $\begin{array}{l}\text { 境界明瞭な多数の低 } \\
\text { 結度節 }\end{array}$ & $\begin{array}{l}\mathrm{T} 2 \text { 強調で境界明瞭な } \\
\text { 低信号の多発結節 }\end{array}$ & 悪性腫清 & 手術 & なし \\
\hline $\begin{array}{l}<12> \\
51 \text { 惄女 }\end{array}$ & $\begin{array}{r}\text { 11) } \\
\text { 津田ら }\end{array}$ & 倦态感 & $\begin{array}{l}\text { 低エコーの } \\
\text { 多発結節 }\end{array}$ & \begin{tabular}{|l} 
境界明暸な多数の低 \\
洁度結節
\end{tabular} & $\begin{array}{l}\text { T1強調でisointensity } \\
\text { T2強調てlowintensity }\end{array}$ & 墨性リンパ & 手術 & なし \\
\hline $\begin{array}{l}<13> \\
71 \text { 骼女 }\end{array}$ & 自匬例 & $\begin{array}{l}\text { 肺サルコイド- } \\
\text { シスで通院中 }\end{array}$ & $\begin{array}{l}\text { 低エコーの } \\
\text { 多発結節 }\end{array}$ & $\begin{array}{l}\text { 境界明暸な多数の低 } \\
\text { 湍度結節 }\end{array}$ & $\begin{array}{l}\text { T2強調で境界明瞭な } \\
\text { 低信号の多発結節 }\end{array}$ & 悪性腫㑸 & 手術 & なし \\
\hline
\end{tabular}


り，他病変がないことから手術を選択した，本症例の

ように腫湯の増大，増加㑯向を認め，他病変を諗めな い症例では確定診断するという点からも手術適応があ ると思われた。

\section{結 語}

今回われわれは比較的稀な脾サルコイドーシスの 1 例を経験した，自験例のように脾原発腫湯との鑑別が 難しい症例では, 確定診断するという意味で手術の適 応があると思われた。

\section{女 嗝}

1) Britt $A R$ : Sarcoidosis : abdominal mahifestations at CT. Radiology 178:91-94, 1991

2）小林洋三：巨大脾腫を伴うサルコイドーシスの2 例. 日胸疾患会詓 $20 ： 1251 ， 1982$

3）井上泉, 畠 信介、山崎幸茂他：脾サルコイド ーシスの1例、日内会誌 $89: 111-113,2000$

4) 福地一樹, 神長達郎, 野口由篹他: 脾サルコイド
ーシスの1症例一画像診断を中心に。日本医放会 誌 $50: 114-145,1990$

5）諸胃里秀和，祝峰千明，石原昌清他：肝脾サルコ イドーシスの1例。日本医放会誌 $57: 56-57$, 1997

6）印牧義英，谷一郎，中島康雄他：肝脾サルコイ ドーシスの1例，日独医報 $44: 183 ， 1999$

7）瑇端静馬, 田伏洋治, 山出尚久他：脾サルコイド ーシスの1例. 日臨外会誌 $62: 742,2001$

8）阿部克巳，横山佳明，牛見尚史地：肝脾サルコイ ドーシスの 2 例.画像診断 $16: 1271-1275,1996$

9) 小林信雄, 海辺文彦, 松迫正樹他：肝脾サルコイ ドーシスの 2 例. 日本医放会誌 $59: 216,1999$

10）長浜実穗，戸巴度五郎，野上隆司：脾サルコイド ーシスの2 例. 日臨外会誌 $59: 411,1998$

11）津田 恭, 村上卓道, 中村仁信他：脾サルコイド ーシスの1例, 臨放線 $38: 613-616,1993$

\title{
A CASE OF SPLENIC SARCOIDOSIS
}

\author{
Tomoichiro HIROSAWA, Akiyoshi SESHIMO. Shingo KA.MEOKA, \\ Masahide MURASUGI* and Yoshimasa ONUKI* \\ Departments of Surgery II and Respiratory Surgery*, Tokyo Iomen's Medical College
}

We present a case of splenic sarcoidosis, which is a relatively rare entity.

A 71-year-old woman, who had been observed clinical course of nodules in the spleen on an abdominal CT scan after surgery for pulmonary sarcoidosis, underwent a splenectomy because the splenic nodules gradually became large and multiple.

There have been 12 cases of splenic sarcoidosis in the Japanese literature, and five out of the 12 cases underwent a splenectomy because a possibility of primary splenic malignancy could not be ruled out and were pathologically diagnosed as splenic sarcoidosis after the operation. In the remaining seven cases without surgery, splenic sarcoidosis was diagnosed by liver biopsies due to associated hepatic lesions. It is believed that splenic sarcoidosis spontaneously cures in $80-90 \%$ of the patients and follows chronic course in the rest. The problems might lie in therapeutic methods for the disease with a propensity to grow and become multiple. The therapies include steroid regimen and surgery. In this case, we selected surgery because the patient's general condition was stable when the splenic tumor increased, no other lesions were present, and a possible primary splenic tumor could not be ruled out. It is thought that such a case might be a candidate for surgery in terms of making the definite diagnosis. 